\title{
ANALISIS CAMPUR KODE PADA GAYA BICARA ANAK MUDA
}

\author{
Ida Ayu Panuntun \\ Universitas Pekalongan \\ e-mail: ayyu idda@yahoo.com
}

\begin{abstract}
ABSTRAK
Gaya bicara anak muda jaman sekarang menjadi sesuatu yang menarik untuk dianalisis. Sebagai pembelajar bahasa kedua, maka peran bahasa pertama atau sebaliknya sering muncul pada percakapan sehari-hari. Tujuan dari penelitian ini adalah menemukan tipe campur kode yang digunakan pada percakapan anak muda. Pada penelitian ini, peneliti menggunakan desain penelitian berupa deskriptif kualitatif. Subyek pada penelitian ini adalah 7 anak muda pada usia 9 sampai 15 tahun. Instrument yang digunakan dalam penelitian ini adalah kuesioner. Teknik analisis pada penelitian ini adalah identifikasi, klasifikasi dan interpretasi. Hasil penelitian menunjukkan bahwa sebanyak $72.7 \%$ menggunakan campur kode tipe intra-sentential, $22.7 \%$ menggunakan tipe intra-lexical dan 1 ucapan 4.5\% menggunakan tipe a change of pronunciation. Prosentase tertinggi campur kode yang muncul pada gaya bicara anak muda adalah tipe intra-sentential, sebagaian besar campur kode yang muncul berupa ucapan berbentuk frasa atau berupa gabungan kata-kata, kemudian Intra-lexical menduduki prosentase lebih kecil dibanding intra-sentential. Hal ini berarti anak muda mencoba menggabungkan dua kata, yaitu Bahasa Indonesia dan Bahasa Inggris dalam satu kata. Sementara temuan dengan prosentase terendah adalah a change of pronunciation. Pada temuan ini gaya bicara anak muda berupa kata-kata Bahasa Inggris yang telah mengalami perubahan suara.
\end{abstract}

Kata kunci: anak muda, campur kode, gaya bicara

\section{PENDAHULUAN}

Penguasaan bahasa bagi setiap individu merupakan kajian yang penuh dengan berbagai tata cara. Tata cara yang dimaksud adalah bagaimana pembentukan bahasa tersebut dan bagaimana pola struktur bahasa yang digunakan dalam setiap komunikasi. Selain dua tata cara di atas, ada satu lagi kajian yang tidak terlepas dari pentingnya memahami kajian bahasa, yaitu faktor yang mempengaruhi terciptanya bahasa pada komunikasi di atas. Faktor terdekat yang memegang peranan penting dalam pembentukan bahasa ini adalah lingkungan.

Lingkungan dimana individu berada merupakan latar belakang utama terciptanya bahasa. Sebagai contoh, seseorang yang tinggal di Pulau Jawa dengan mayoritas penduduknya menggunakan bahasa Jawa, maka akan menjadikan Bahasa Jawa sebagai bahasa sehari-hari. Oleh karena itu, ketika masyarakat Jawa terlibat dalam percakapan dengan menggunakan Bahasa Indonesia, maka terkadang mereka masih mencampur dengan bahasa keseharian mereka, yaitu Bahasa Jawa. Mengapa demikian? Hal ini dikarenakan percakapan dalam Bahasa Indonesia itu diikuti oleh para pelaku yang berasal dari Pulau Jawa.

Generasi muda sekarang ini sarat dengan berbagai fasilitas canggih sebagai pendukung dalam perkembangan diri. Fasilitas yang dimaksud adalah berupa IImu 
Pengetahuan dan Teknologi (IPTEK). Selain itu, era modernisasi juga sangat mempengaruhi gaya hidup para generasi muda. Dalam beberapa kegiatan baik secara langsung maupun tidak, generasi muda ini dihadapkan dengan penggunaan bahasa internasional, yaitu Bahasa Inggris. Banyak dari mereka yang secara sadar mencoba mengkombinasi penggunaan Bahasa Inggris dalam percakapan sehari-hari. Berikut salah satu contoh penggalan percakapan Bahasa Indonesia yang menyisipkan kosakata Bahasa Inggris:
A : Gimana, jadi ga?
B : Jadi apa?
A : Cari lukisan
B : Oh ya.. OK..Let's go.

Penggalan dialog antara A dan B di atas merupakan dialog dengan menggunakan Bahasa Indonesia. Akan tetapi, pada salah satu ucapan dari pelaku percakapan tersebut telah menggunakan Bahasa Inggris. Contoh percakapan di atas adalah salah satu contoh percakapan yang menggunakan campur kode pada ucapannya. Campur kode ini muncul dalam Bahasa Inggris, yaitu "... Let's go."

Campur kode yang ditemukan pada contoh di atas merupakan salah satu pilihan yang biasa dilakukan oleh para pelaku tindak komunikasi dwibahasa. Pada penelitian ini ditemukan beberapa ucapan yang muncul dengan menggunakan Bahasa Inggris pada percakapan antara anak muda jaman sekarang. Dalam percakapan sehari-hari ketika mereka berkumpul bersama, hal ini sering terjadi.

Percampuran bahasa sering sekali ditemukan dalam komunikasi sehari-hari. Percampuran bahasa dalam komuikasi dikenal dengan sebutan campur kode.

Menurut Saddhono (2012: 75), campur kode adalah pemakaian bahasa atau lebih dengan saling memasukan unsur bahasa yang satu ke bahasa yang lain. Selain pengertian campur kode berdasarkan Saddhono, pendapat lain juga muncul berdasarkan Subyakto. Subyakto (dalam Suwandi (2010)) mengemukakan bahwa campur kode adalah penggunaan dua bahasa atau lebih atau ragam bahasa secara santai antara orang-orang yang kita kenal dengan akrab. Menurut Kridalaksana (2001), campur kode adalah penggunaan satuan bahasa dari satu bahasa ke bahasa lain untuk memperluas gaya bahasa atau ragam bahasa, termasuk di dalamnya pemakaian kata, klausa, idiom, sapaan dan sebagainya.

Berdasarkan beberapa pengertian campur kode di atas, maka dapat disimpulkan bahwa campur kode adalah penggunaan lebih dari satu bahasa dalam suatu komunikasi untuk tujuan tertentu. Campur kode ini sering sekali terjadi. Terkadang campur kode tersebut muncul dikarenakan melihat lingkungan yang melatari terjadinya percakapan. Hubungan antara para pelaku percakapan menjadi dasar terciptanya campur kode.

Ada beberapa tipe campur kode dalam suatu komunikasi. Berdasarkan pernyataan Hoffman (1991), dapat diketahui bahwa ada tiga tipe campur kode. Berdasarkan pada hubungan sintaksis. Ketiga tipe campur kode yang dimaksud adalah:

a) Intra-sentential

Intra-sentential merupakan salah satu tipe campur kode menurut Hoffman yang berkaitan dengan frasa dan kalimat. Tipe campur kode model ini tampak pada percakapan di bawah ini:

A : Sebaiknya kamu letakan gelas di atas meja. 
B : Iya, don't worry, akan segera aku pindahkan.

Pada contoh percakapan di atas, antara para pelaku yaitu A dan B menggunakan Bahasa Indonesia. Akan tetapi pada salah satu tuturan terselip frasa dalam Bahasa Inggris. Oleh karena itu, contoh percakapan di atas adalah ucapan dengan menggunakan campur kode.

b) Intra lexical

Tipe yang kedua ini adalah tipe campur kode yang muncul pada ikatan kata. Contoh pada percakapan berikut:

A : Kuotaku habis, jadi tidak bisa ikut nge-like.

B : Ya sudah.

Pada salah satu kata dalam tuturan di atas, muncul ikatan kata yang mencampur penggunaan Bahasa Inggris dalam Bahasa Indonesia. Kata yang dimaksud adalah nge-like.

\section{c) A change of pronunciation}

Tipe ini menunjukkan adanya perubahan suara atau dikenal dengan istilah phonological. Contoh pada penggunaan kata "hello", campur kode dalam Bahasa Indonesia muncul dengan pengucapan "halo."

Sebagaimana disebutkan mengenai pengertian campur kode di atas, maka dapat diketahui bahwa campur kode biasa terjadi di kalangan para pelaku komunikasi dua bahasa, atau sering dikenal dengan istilah dwibahasa.

Perilaku dwibahasa merupakan perilaku yang muncul dari individu dalam menguasai lebih dari satu ragam bahasa dan menggunakannya dalam percakapan pada saat yang bersamaan. Menurut Mackey (dalam Aslinda dan Syafyanhya: 2007) menjelaskan bahwa dalam membahas peristiwa kedwibahasaan tercakup beberapa pengertian, seperti masalah tingkat, fungsi, pertukaran atau alih kode, percampuran atau campur kode, interferensi dan integrase. Pendapat lain muncul dari Hoffmann (1991). Hoffmann (1991) menjelaskan "several reasons why bilinguals and multilinguals switch or mix their language, it is ranging from talking about a particular topic, quoting somebody else, being emphatic about something, interjection (inserting sentence connectors), repetition used for clarification, intention of clarifying the speech content for interlocutor and expressing group entity". Berdasarkan pendapat Hoffmann di atas, dapat disimpulkan bahwa ada beberapa alasan mengapa bilingual dan multilingual mencampur bahasa, yaitu membicarakan topik tertentu, mengutip orang lain, berempati, menyisipkan penghubung kalimat dan perulangan untuk sebuah klarifikasi. Melalui beberapa pandangan pakar mengenai peristiwa kedwibahasaan dapat ditarik kesimpulan bahwa peristiwa kedwibahasaan meliputi beberapa pokok bahasan, salah satunya adalah campur kode yang sering terjadi dengan didasari oleh alasan tertentu.

Komunikasi lebih dari satu bahasa sering terjadi pada komunikasi informal. Menurut Mulyana (2001), saluran informal terbentuk dari kesamaan kepentingan di antara orang-orang dalam komunikasi. Oleh karena itu, ketika beberapa orang berkumpul dalam suatu komunitas dalam situasi informal terkadang menyebabkan munculnya campur kode pada percakapan yang terjadi.

Berdasarkan latar belakang di atas, maka tujuan dari penelitian ini adalah menemukan tipe campur kode yang muncul pada percakapan anak muda. 


\section{METODE PENELITIAN}

Pada penelitian ini, peneliti menggunakan metode penelitian berupa deskripstif kualitatif. Metode ini dianggap penting untuk memahami suatu fenomena sosial dan perspektif individu yang diteliti. Berdasarkan pendapat di atas maka metode kualitatif adalah suatu metode yang memiliki langkah pemecahan masalah berupa deskripsi keadaan subyek atau obyek penelitian yang sebenarnya. Hal ini dimaksudkan bahwa data yang ada didukung oleh fakta di lapangan. Subyek pada penelitian ini adalah 7 anak muda yang berusia antara 9 hingga 15 tahun yang membahas mengenai media sosial. Teknik analisis data yang digunakan pada penelitian ini adalah identifikasi, klasifikasi dan interpretasi.

\section{HASIL PENELITIAN DAN PEMBAHASAN}

Tujuan dari penelitian ini adalah untuk menemukan tipe campur kode yang muncul pada percakapan anak muda. Berdasarkan analisis data yang telah dilakukan, maka diperoleh hasil sebagai berikut:

Tabel 1. Analisi data berdasarkan tipe campur kode

\begin{tabular}{|c|c|c|c|c|}
\hline \multirow[t]{2}{*}{ No. } & \multirow[t]{2}{*}{ Ucapan } & \multicolumn{3}{|c|}{ Tipe Campur Kode } \\
\hline & & $\begin{array}{c}\text { Intra- } \\
\text { sentential }\end{array}$ & $\begin{array}{l}\text { Intra } \\
\text { lexical }\end{array}$ & $\begin{array}{l}\text { A change of } \\
\text { pronunciation }\end{array}$ \\
\hline 1. & By the way, kita mau lanjut kemana ini? & $\sqrt{ }$ & & \\
\hline 2. & Menurutku nge-game lebih asik. & & $\sqrt{ }$ & \\
\hline 3. & Dia yang minta aku nge-like. & & $\sqrt{ }$ & \\
\hline 4. & Ini mudah kok, don't worry. & $\mathrm{V}$ & & \\
\hline 5. & Well, kita lihat yang ini dulu. & $\sqrt{V}$ & & \\
\hline 6. & $\begin{array}{l}\text { Hello (halo), aku masing bingung dengan } \\
\text { yang ini. }\end{array}$ & & & $\mathrm{V}$ \\
\hline 7. & Masalah kecil, no problem. & $\mathrm{V}$ & & \\
\hline 8. & Nanti jangan lupa, chat aku ya. & $\mathrm{V}$ & & \\
\hline 9. & Yang ini bisa di-combine langsung. & & $\sqrt{ }$ & \\
\hline 10. & Kemarin sudah di-update adikku. & & $\sqrt{ }$ & \\
\hline 11. & $\begin{array}{l}\text { Aku sudah buka yang ini and yang satunya } \\
\text { juga. }\end{array}$ & $\sqrt{ }$ & & \\
\hline 12. & Kalau aku pilih channel yang lama. & $\mathrm{V}$ & & \\
\hline 13. & Dia lagi sibuk kirim message. & $\sqrt{ }$ & & \\
\hline 14. & $\begin{array}{l}\text { Langkahnya memang seperti itu, then } \\
\text { langkah berikutnya baru yang ini. }\end{array}$ & $\mathrm{v}$ & & \\
\hline 15. & Bantu aku please. & $\mathrm{V}$ & & \\
\hline 16. & Manis banget coklatnya, thank you ya. & $\mathrm{V}$ & & \\
\hline 17. & Tadi di-mix dengan sedikit gula. & & $\sqrt{ }$ & \\
\hline 18. & Baiklah, forgive me. & $\mathrm{V}$ & & \\
\hline 19. & Aku lelah, so berhenti dulu. & $\mathrm{V}$ & & \\
\hline 20. & Ini cocok sekali, but mahal juga ya. & $\mathrm{V}$ & & \\
\hline 21. & Untuk step berikutnya, pakai yang ini saja. & $\mathrm{V}$ & & \\
\hline 22. & Model yang ini enough. & $\mathrm{V}$ & & \\
\hline
\end{tabular}


Berdasarkan data pada Tabel 1. di atas maka dapat diperoleh data bahwa dari percakapan yang terjadi antara 7 anak yang terlibat dalam percakapan, diperoleh data sebanyak 22 ucapan yang telah menggunakan campur kode. Ke-22 ucapan tadi dideskripsikan dan diperoleh data 16 ucapan diidentifikasi ke dalam ucapan yang menggunakan campur kode tipe intra-sentential, 5 ucapan masuk ke dalam kategori intra-lexical dan 1 ucapan merupakan campur kode tipe a change of pronunciation.

Berikut beberapa contoh analisis pada data di atas:

a) Analisis data berupa ucapan yang tipe campur kode intra-sentential.

Data berikut muncul pada percakapan antara A dan B. Percakapan tersebut terjadi di lapangan. Di bawah ini adalah data percakapan antara A dan B.

A : Hai Di, bagaimana kabarmu?

B : Baik. Kamu kemarin kemana, aku cari di rumah ga ada?

A : lya, aku keluar sebentar. By the way kita mau lanjut kemana ini.

B : Aku ngikut saja.

Percakapan tersebut terjadi antara teman sebaya. Percakapan tersebut menggunakan Bahasa Indonesia. Akan tetapi, pada salah satu ucapan yang disampaikan oleh A, ditemukan ada frasa berbahasa Inggris. Oleh karena itu, data tersebut menunjukkan bahwa ucapan berupa kalimat tersebut menyisipkan frasa berbahasa Inggris, sehingga salah satu pelaku percakapan tersebut telah menggunakan tipe campur kode yang dinamakan tipe intra-sentential.

Contoh berikutnya adalah percakapan yang terjadi antara B dan E. Percakapan tersebut juga terjadi di lapangan. Mereka berdua adalah teman sebaya. Berikut data percakapan antara B dan E:

B : Kamu setuju ga kita kesana?

E : Belum tahu ne. Well, kita lihat yang ini dulu.

B : Wah, boleh juga ne.

Berdasarkan data ucapan dalam percakapan di atas E secara sengaja menggunakan kata dalam Bahasa Inggris. Padahal percakapan tersebut adalah percakapan yang menggunakan Bahasa Indonesia. Berdasarkan data tersebut, dapat disimpulkan bahwa E telah menggunakan campur kode dengan tipe intra-sentential.

b) Analisis data berupa ucapan yang tipe campur kode intra-lexical.

Analisis berikutnya adalah percakapan yang mengandung tipe campur kode intra-lexical. Berikut adalah contoh percakapan yang dimaksud, yaitu percakapan yang terjadi antara A dan C. Lokasi percakapan tersebut terjadi di lapangan.

A : Kemarin akunku kok ga bisa dipakai ya.

C : Oh begitu, dulu punyaku juga seperti itu.

A : Terus bagaimana?

C : Bisa kok, kemarin sudah di-update adikku.

A : Ternyata begitu caranya ya.

Contoh di atas adalah contoh percakapan yang salah satu ucapannya menggunakan campur kode tipe intra-lexical. Campur kode tipe intra-lexical tersebut tampak pada ucapan C "Bisa kok, kemarin sudah di-update adikku." Kata di-update 
merupakan ikatan kata yang menyisipkan kata update (dalam Bahasa Inggris) ke dalam kata Bahasa Indonesia.

c) A change of pronunciation

Tipe $A$ change of pronunciation tampak pada percakapan berikut.

D : Jangan dibuat sulit.

E : Yang ini kan?

D : lya, mudah kan?

E : Hello (halo), aku masing bingung dengan yang ini.

D : Perhatikan caraku.

Berdasarkan percakapan antara D dan E yang berlatar di lapangan, dapat diketahui bahwa E telah menyisipkan kata dalam Bahasa Inggris, yaitu Hello. Akan tetapi, E mengucapkannya dengan cara pengucapan dalam Bahasa Indonesia. Oleh karena itu, E telah menggunakan campur kode dengan tipe $A$ change of pronunciation.

\section{KESIMPULAN}

Gaya bicara pada anak muda jaman sekarang menjadi sesuatu yang baru dan menarik. Banyak dari mereka yang mencampur ragam percakapan dalam Bahasa Indonesia ke dalam Bahasa Inggris. Berdasarkan pada hasil penelitian di atas, ditemukan sebanyak 16 ucapan, yaitu sebanyak $72.7 \%$ menggunakan campur kode tipe intrasentential, 5 ucapan (22.7\%) intra-lexical dan 1 ucapan (4.5\%) merupakan tipe a change of pronunciation. Temuan di atas merupakan banyaknya campur kode yang telah terjadi pada gaya bicara anak muda. Prosentase tertinggi campur kode yang muncul adalah tipe intra-sentential. Hal ini berarti campur kode yang muncul berupa ucapan berbentuk frasa atau berupa gabungan kata-kata. Prosentase kedua adalah intra-lexical. Hal ini berarti anak muda mencoba menggabungkan dua kata, yaitu Bahasa Indonesia dan Bahasa Inggris dalam satu kata. Sebagai contoh nge-like. Temuan yang terakhir adalah a change of pronunciation. Pada temuan ini gaya bicara anak muda berupa kata-kata Bahasa Inggris yang telah mengalami perubahan suara, missal hello diucapkan dengan halo.

\section{SARAN}

Hasil dari penelitian ini dapat menjadi kontribusi untuk para anak muda dalam mempelajari campur kode sehingga dapat meminimalisir penggunaan campur kode dalam percakapan sehari-hari mereka.

\section{DAFTAR PUSTAKA}

Heryanto, Yusuf. (2010). Ikhtisar Ilmu Bahasa. Bogor: Media Ilmiah dan STKIP Muhammadiyah.

H.P., Achmad dan Abdullah, Alek. (2012). Linguistik Umum. Jakarta: Erlangga.

Hoffmann, C. (1991). An Introduction to Bilingualism. London: Longman.

Mahootian, S. (2006). Code Switching and Mixing. In K. Brown (Ed.), Encyclopedia of Language and Linguistics. Oxford: Elsivier. 
Margana. (2012). Alih Kode dalam Pengajaran Bahasa Inggris di SMA di Daerah Istimewa Yogyakarta., dalam disertasi. Yogyakarta: Universitas Gadjah Mada.

Maulidini, Ratna. (2007). Skripsi. Campur Kode sebagai Strategi Komunikasi Customer Service. Semarang: Retrieved from: http://eprints.undip.ac.id/5344/1/SKRIPSI.pdf.

Mulyana, Deddy. (2001). Prinsip-prinsip Dasar Komunikasi. Bandung. Remaja Rosda Karya.

Muysken, P. (2000). Bilingual Speech: A Typology of Code-Mixing. United Kingdom: Cambridge University Press.

Saddhono, Kundharu. (2012). Pengantar Sosiolinguistik (Teori dan Konsep Dasar). Surakarta: Universitas Sebelas Maret.

Sudaryanto, (2001). Metode dan Aneka Teknik Analisis Bahasa. Yogyakarta. Duta Wacana University Press.

Sujana dan Hartati, Sri. (2009). Campur Kode Bahasa Inggris dalam Percakapan di Facebook. Jakarta: Universitas Gunadarma.

Sutopo. (2002). Penelitian Kualitatif. Surakarta: Sebelas Maret University Press.

Suwandi, Sarwiji. (2010). Serba Linguistik. (Mengupas Pelbagai Praktik Bahasa). Surakarta: Universitas Sebelas Maret.

Syamsuddin dan Damaianti, V. (2006). Metode Penelitian Pendidikan Bahasa. Bandung: PT Remaja Rosdakarya

Wijaya, I Dewa Putu\&Rohmadi, Muhammad. (2012). Sosiolinguistik. (Kajian Teori dan Analisis). Yogyakarta: Pustaka Pelajar. 